\title{
IDENTIFIKASI SIKAP EMPATI PENGASUH PADA ANAK BINAAN PANTI ASUHAN
}

\author{
Rauzatul Ulya, M. Jamil Yusuf, Syaiful Indra \\ Program Studi Bimbingan dan Konseling Islam, Universitas Islam Negeri Ar Raniry \\ e-mail: syaiful.indra@ar-raniry.ac.id
}

\begin{abstract}
Abstrak. Empati adalah kemampuan merasakan emosi orang lain baik secara fisiologis maupun mental yang terbangun pada berbagai keadaan batin orang lain. Perubahan biologis ini akan muncul ketika individu berempati dengan orang lain. Hal yang tidak sesuai dengan diharapkan adanya pengasuh yang cuek, tidak peduli dan antipati, sehingga membuat anak asuh tidak berani berkomunikasi langsung dengan pengasuhnya sehingga membuat anak asuh kurang nyaman dan betah tinggal di panti asuhan. Oleh karena itu yang menjadi tujuan umum penelitian ini yaitu: untuk mengetahui identifikasi sikap empati pengasuh pada anak binaan pada Panti Asuhan Bumi Moro Kecamatan Darul Imarah Kabupaten Aceh Besar. Sedangkan tujuan khususnya yaitu: untuk mengetahui bentuk-bentuk empati pengasuh dalam pengasuhan anak binaan, untuk mengetahui sikap pengasuh yang menunjukkan empati pada anak binaan dilihat dari verbal dan non verbal, untuk mengetahui respon anak binaan terhadap empati yang diberikan oleh pengasuh. Metode yang digunakan adalah deskriptif pendekatan kualitatif. Teknik pengumpulan data menggunakan observasi, dokumentasi dan wawancara dengan teknik purposive sampling dengan 5 kriteria dan 7 orang responden, teknik analisis data menggunakan reduksi data, penyajian data, penarikan kesimpulan. Hasil yang di peroleh dalam penelitian ini meliputi: (1) Bentuk-bentuk empati pengasuh dalam pengasuhan anak binaan sudah berhasil dilakukan dengan cara memeluk, meranggkul dan mengusap kepala anak asuh ketika mendengarkan persoalan yang dialami anak asuh di panti asuhan. (2) Sikap pengasuh yang menunjukkan empati pada anak binaan dilihat dari verbal dan non verbal pengasuh sudah memberikan perhatikan terhadap anak asuh dengan cara menjenguk anak asuh ke kamar, duduk bersama anak asuh, ikut makan bersama dan sebagainya sehingga anak asuh merasa ada yang peduli terhadap dirinya. (3) Respon anak binaan terhadap empati yang diberikan oleh pengasuh diketahui bahwa anak asuh bahagia dan nyaman tinggal di panti asuhan karena memiliki pengasuh yang lemah lembut dan perhatian terhadap diri anak asuh. Berdasarkan hasil penelitian dapat disimpulkan bahwa sikap empati pengasuh dapat membantu mengetahui perasaan dan kondisi yang dialami oleh anak binaan.
\end{abstract}

Kata kunci: Sikap Empati, Pengasuh, Panti Asuhan

\begin{abstract}
Empathy is the ability to feel the emotions of others both physiologically and mentally that is awakened in various mental states of others. These biological changes will arise when individuals empathize with others. It is not in accordance with the expected caregivers who are ignorant, uncaring and antipathy, so that foster children do not dare to communicate directly with their caregivers, making foster children less comfortable and at home in orphanages. Therefore the general objective of this study is: to identify the attitudes of caregiver empathy for fostered children at Bumi Moro Orphanage, Darul Imarah District, Aceh Besar District. While the specific objectives are: to find out the forms of empathy of caregivers in caring for fostered children, to find out the caregivers' attitudes that show empathy in fostered children viewed from verbal and non verbal, to find out the response of fostered children to empathy given by caregivers. The method used is descriptive qualitative approach. Data collection techniques using observation, documentation and interviews with purposive sampling technique with 5 criteria and 7 respondents, data analysis techniques using data reduction, data presentation, drawing conclusions. The results obtained in this study include: (1) The forms of empathy of caregivers in the care of fostered children have been successfully carried out by bugging, embracing and rubbing the head of foster children when listening to problems experienced by foster
\end{abstract}


children in the orphanage. (2) The caregiver's attitude that shows empathy for the fostered child is seen from the verbal and non-verbal caregivers already giving attention to the foster children by visiting foster children to the room, sitting with foster children, sharing meals and so on so that the foster children feel someone cares about himself. (3) Fostered children's response to empathy given by caregivers is known that foster children are happy and comfortable living in orphanages because they have gentle caregivers and attention to themselves. Based on the results of the study it can be concluded that the caregiver's empathy can help find out the feelings and conditions experienced by the target children.

Keywords: Empathy Attitudes, Caregivers, Orphanages

\section{PENDAHULUAN}

Panti Asuhan sebagai tempat tumbuh dan berkembang seorang anak yang di titipkan oleh orang tua atau keluarganya. Di samping itu anak membutuhkan seorang pengasuh yang mempunyai jiwa sosial tinggi dan mengerti tentang pengasuhan, yang seharusnya diterapkan kepada anak asuhnya. Karena pengasuh adalah sebagai pengganti orang tua untuk anak. Pengasuh di panti asuhan berfungsi sebagai lembaga sosial di mana dalam kehidupan sehari-hari, anak diasuh, dididik, dibimbing, diarahkan, diberi kasih sayang, dicukupi kebutuhan sehari-hari dan diberi ketrampilan-ketrampilan. Agar anak tidak kehilangan suasana seperti dalam keluarga, panti asuhan berusaha memberikan pelayanan yang terbaik pada mereka dan menggantikan peran keluarga bagi anak. Anak-anak asuh yang ada di panti asuhan perlu di berikan pembinaan yang tepat agar anak asuh tidak bergantung kepada orang lain, dan menjadi masyarakat yang mandiri tanpa membebani masyarakat lain.

Pengasuhan yang menjadi tanggung jawab orang tua beralih kepada pengasuh di panti asuhan. Para pengasuh memiliki kewajiban untuk memenuhi kebutuhan fisik dan psikis anak dan hal ini di dukung oleh lembaga yang menanganinya, yakni panti asuhan. Idealnya Panti Asuhan tidak sekedar memenuhi kebutuhan biologis dan fisiologis (makan, minum, tidur, dan sebagainya) maupun pendidikan dalam arti formal (sekolah) tapi juga dibarengi dengan pendidikan yang bersifat non formal yakni pembinaan tehadap kepribadian anak.

Di dalam kehidupan sehari-hari pengasuh harus mempunyai sikap empati kepada anak, karena sikap empati sangat berperan penting dan menjadi pegangan bagi pengasuh untuk bertingkah laku. Sikap empati tersebut seperti sikap empati pengasuh pada anak panti asuhan, yang di lihat dari kepedulian pengasuh terhadap anak asuh, membina, menjaga atau merawat anak asuh, dan juga adanya sikap penyayang pengasuh terhadap anak panti asuhan. Tujuannya supaya anak panti asuhan betah dan senang tinggal di panti asuhan. 
Empati adalah kemampuan merasakan emosi orang lain baik secara fisiologis maupun mental yang terbangun pada berbagai keadaan batin orang lain. Perubahan biologis ini akan mencul ketika individu berempati dengan orang lain. Prinsip umumnya, semakin sama keadaan fisiologis dua orang pada momen tertentu, semakin mudah pula mereka bisa merasakan perasaannya satu sama lain (Davis, 2019).

Empati sangat di perlukan oleh seorang pengasuh di panti asuhan, supaya pengasuh harus memahami perasaan atau masalah anak asuh, kemudian akan menciptakan sosialisasi atau interaksi positif terhadap anak serta menumbuhkan rasa kasih sayang dan perhatian kepada anak asuh di panti asuhan. Supaya adanya kedekatan antara pengasuh dengan anak asuh.

Idealnya pengasuh memiliki peran yang tidak jauh berbeda dari orang tua kandungnya, yaitu mencukupi kebutuhan anak dan memberikan pembinaan, dan juga menerapkan prinsipprinsip empati pada diri pengasuh terhadap anak asuhnya. Agar anak asuh senang dengan keberadaannya, jika pengasuh itu hangat, sabar, dan perhatian terhadap anak. Pengasuh harus bersikap empati dengan anak asuh supaya tidak tumbul adanya pengasuh yang kejam dan ditakuti. Pengasuh harus sering komunikasi dengan anak asuh mengenai apa saja yang mau dilakukan kegiatan di panti asuhan, karena itu menjukkan kedekatan antara anak dengan pengasuh, dan juga pengasuh berusaha untuk tetap menjaga hubungan supaya anak dapat terbuka dan merasakan adanya pengganti orang tua yang menyayanginya di panti asuhan. Dengan ini pengasuh harus menerima, merespon, menghargai dan bertanggung jawab atas anak asuh yang dititipkan oleh orang tua atau keluarganya.

Penulis mendapati banyak masalah yang terjadi dan tidak sesuai yang diharapkan. Dari observasi awal penulis pada tanggal 26 Agustus 2019 dengan beberapa anak panti asuhan Bumi Moro, penulis mendapatkan bahwa ada anak yang belum mendapatkan sikap empati dari pengasuh. Hal ini ditunjukkan adanya pengasuh yang cuek, tidak peduli dan antipati, sehingga membuat anak asuh tidak berani berkomunikasi langsung dengan pengasuhnya.

Berdasarkan latar belakang di atas, dapat dilihat maka peneliti merasa tertarik untuk mengkaji lebih dalam tentang sikap empati pengasuh terhadap anak asuhnya, sehingga penulis mengangkat judul penelitian "Sikap Empati Pengasuh Pada Anak Binaan Panti Asuhan Bumi Moro Kecamatan Darul Imarah Kabupaten Aceh Besar”.

Tujuan penulisan penulis secara umum adalah untuk mengetahui identifikasi sikap empati pengasuh pada anak binaan di Panti Asuhan Bumi Moro Kecamatan Darul Imarah Kabupaten Aceh Besar. 


\section{METODE}

Penulis menggunakan penelitian deskriptif, yakni suatu metode dalam meneliti suatu objek, suatu sistem pemikiran atau suatu kilas peristiwa pada masa sekarang. Tujuan dari penelitian deskriptif adalah untuk membuat deskripsi, gambaran atau lukisan secara sistematis faktual dan akurat mengenai fakta-fakta, sifat-sifat serta hubungan antara fenomena yang diselidiki (Moleong, 2006). Penelitian deskriptif (descriptive research), yang biasa disebut juga penelitian taksonomik (taxsonomic research), dimaksudkan untuk eksplorasi dan klarifikasi mengenai sesuatu fenomena atau kenyataan sosial, dengan jalan mendeskripsikan sejumlah variabel yang berkenaan dengan masalah dan unit yang diteliti (Faisal, 2010).

Adapun jenis penelitian yang dilakukan oleh peneliti adalah penelitian lapangan (field research). Penelitian lapangan dilakukan di lokasi yang sudah dipilih oleh peneliti, sebagai tempat untuk menyelidiki gejala objektif yang terjadi di lokasi tersebut serta dilakukan juga untuk laporan ilmiah.

Penelitian ini dilakukan untuk menggali informasi agar dapat menemukan penjelasan mengenai sikap empati pengasuh dalam pembinaan anak Panti Asuhan Bumi Moro Kecamatan Darul Imarah Kabupaten Aceh Besar. Dengan demikian yang dimaksud penulis dalam penelitian ini yaitu penulis berusahan menggambarkan dan mendeskripsikan kembali apa yang dilhat, didengar dan yang dibaca dari hasil dokumentasi yang ada di Panti Asuhan Bumi Moro Kecamatan Darul Imarah Kabupaten Aceh Besar.

Lokasi yang dipakai oleh peneliti dalam penelitian ini adalah di Panti Asuhan Bumi Moro Jl. Reubek N0.45 Kecamatan Darul Imarah Kabupaten Aceh Besar. Panti Asuhan tersebut menampung anak yatim, piatu, yatim piatu dan duafa. Populasi penelitian ini adalah untuk mengetahui bagaimana sikap empati pengasuh dalam pembinaan anak Panti Anak Asuhan Bumi Moro Kecamatan Darul Imarah Kabupaten Aceh Besar.

Untuk menentukan dan memperoleh data yang diperlukan dalam penelitian skripsi ini penulis menggunakan sumber data primer dan sumber data sekunder.

\section{Data Primer}

\section{Data Sekunder}

Dalam penelitian ini penulis menggunakan teknik purposive sampling yaitu pengambilan sampel berdasarkan pertimbangan tertentu, misalnya orang tersebut adalah orang yang dianggap yang paling tahu tentang apa yang diharapkan oleh penulis (Sugiyono, 2013). Pengambilan sample ini disesuaikan dengan kriteria subjek penelitian. Cara semacam ini merupakan non random karena tidak semua anggota populasi mendapatkan peluang untuk terpilih sebagai anggota sample (Pohan, 2007). 
Subjek penelitian yang dijadikan sumber informasi oleh peneliti karena mempertimbangkan benyaknya jumlah pengasuh 5 orang dan anak asuh berjumlah 30 orang. Maka subjek penelitian yang dijadikan sumber informasi dengan kriteria sebagai berikut:

1. Pimpinan Panti Asuhan Bimi Moro

2. Pengasuh laki-laki yang menetap di Panti Asuhan

3. Pengasuh perempuan yang menetap di Panti Asuhan

4. Anak asuh laki-laki yang sudah lama tinggal di Panti Asuhan

5. Anak asuh perempuan yang sudah lama tinggal di Panti Asuhan

\section{HASIL}

Dalam sub bagian ini akan dibahas tiga aspek bagian hasil temuan penelitian yaitu: (1) Empati pengasuh terhadapat anak binaan di Panti Asuhan Bumi Moro, (2) Pengasuh menerapkan sikap empati pada anak binaan di Panti Asuhan Bumo Moro, dan (3) Kepekaan pengasuh dalam mengurus anak binaaan di Panti Asuhan Bumi Moro.

\section{Bentuk-bentuk empati pengasuh dalam pengasuhan anak binaan di Panti Asuhan Bumi Moro.}

Berdasarkan hasil wawancara dengan ibu HN pada tanggal 21 Desember 2019 dapat diuraikan sebagai berikut:

"Iya saya sebagai pengasuh disini memahami perasaan anak asub dan saya memang harus memahami perasaan-perasaan anak asub supaya saya pun mudah menyesuaikan diri dengan anak asub yang satu dengan yang lain, saya bahkean sering mengusap kepala anak asub, memeluk, merangkul ketika anak sedang sedih karna itu rasa kasih sayang saya kepada anak asub disini yang tinggal disini, karena mereka selama tinggal disini ada yang merasa senang karena banyak kawan babkan ada juga yang saya liat ada anak asub yang sedih suka murung sendiri karena ingin di jenguk oleh keluarganya. Kami di sini sebagai pangasuh sering mengajak duduk bersama, bercerita bersama, ikut serta makan bersama supaya mereka merasa ada pengganti orang tua yang mendampingi dia di panti asuhan."

Dari hasil data penelitian diatas dapat disimpulkan bahwa pengasuh sudah berempati dengan baik untuk memahami perasaan atau kondisi anak asuh di panti asuhan. Dengan itu pengasuh selalu memberikan empati kepada asuh asuh seperti memeluk, merangkul dan menenangkan perasaan anak asuh ketika sedih atau dalam persoalan yang dialami anak asuh. pengasuh juga mengontrol anak asuh dengan cara menanyakan keadaan anak asuh, dan sering berkumunikasi dengan anak asuh supaya bisa memahami perasaan anak-anak asuh di panti asuhan. 
Berdasakan hasil wawancara dari anak asuh perempuan SH, pada tanggal 21 Desember 2019, anak asuh SH mengatakan:

"Saya senang tinggal di panti asuhan karena pengasub di sini baik, lemah lembut dan enak di ajak bicara. Babkan pengasub mau memeluk atau merangkul saya ketika saya sedang sedih. Walaupun permasalahan atau perasaan yang saya alami saya tidak sepenubnya menceritakan kepengasub langsung karna merasa segan, merasa saya tidak terlalu dekat dengat pengasuh disini, jarang biacara-bicara berdua dengan pengasuh, kecuali pas lagi ada kegiatan saja makanya saya merasa sedikit segan. Saya di sini juga tidak merasa kesepian bahkan betah tinggal di panti asuban karna mempunyai banyak teman-teman."

Dari hasil data penelitian diatas dapat disimpulkan bahwa anak asuh sudah memiliki kedekatan dengan pengasuhnya, karna semua permasalahan yang di alami oleh anak asuh bisa diceritakan kepada pengasuhnya langsung, bahkan pengasuh memberikan bentuk empati kepada anak asuh seperti memeluk, merangkul dan mengusap kepala anak asuh untuk menenangkan perasaan anak asuh, jadi anak asuh sudah mendapatkan kasih sayang orang tua dari dalam diri pengasuh di panti asuhan.

\section{Sikap pengasuh yang menunjukkan empati pada anak binaan dilihat dari verbal dan non verbal binaan di Panti Asuhan Bumo Moro}

Berdasarkan hasil wawancara dengan ibu HN pada tanggal 21 Desember 2019 dapat diuraikan sebagai berikut:

"Cara saya memperhatikan kondisi anak asuh saya sering menjenguk keadaan anak kekeamarnya, selalu mengecek apa semua anak asub sudah makan, ada belajar babkan sampai mereka tidur kadang-kadang. Saya sangat pribatin kalau ada anak asub yang suka sendiri, sedih dan sakit makanya saya selalu memperhatikan kondisi-kondisinya dan saya disini selalu memberikan semangat pada anak asub supaya anak-anak di sini betah tinggal dinggal di panti asuban."

Dari hasil data penelitian diatas dapat disimpulkan bahwa pengasuh selalu memperhatikan dan peduli terhadap anak asuh karena adanya rasa kekhawatiran, seperti sering menjenguk anak asuh ke kamar, sering duduk bersama anak asuh, ikut makan bersama dan sebagainya dengan tujuan bisa berinteraksi atau menyapa dengan anak asuh supaya anak asuh merasa ada yang peduli dan senang tinggal di panti asuhan. Namun pengasuh tidak mendekati dan mempertikan kondisi anak asuh satu persatu karna jumlah anak asuh lebih banyak dari pada pengasuh yang tinggal di panti asuhan. Oleh karena itu pengasuh memperhatikannya atau mendekatinya malalui kelompokkelompak yang ditetapkan.

Berdasakan hasil wawancara dari anak asuh laki-laki MH, pada tanggal 23 Desember 2019, anak asuh MH mengatakan:

"Cara pengasub disini memperhatikan saya paling nantik sekali-sakali pengasub keekamar kami untuk. liat keadaan dan menyapa seperti menanyakan keadaan kami sehat atau tidak, pengasub disini sangat baik. kak, diingatan biar kami belajar, tapi aja juga dalam sehari tu pengasuh gak pernah liat kami kekeamar sampai 
kami bangun tidur makan sendiri dan langsung kesekolah. Karna di sini kami mandiri sendiri juga kak dan enaknya kami di sini kalo sama pengasuh sering juga nonton bersmana nantik bercerita-becerita jadi bisa diajak becanda juga kak tapi kalo pengasub tu marah itu iya kami takut kali kak. karna suka merepet, maunya pas disurub tu kita harus cepat-capat bangun dan kerjain apa yang disurubnya."

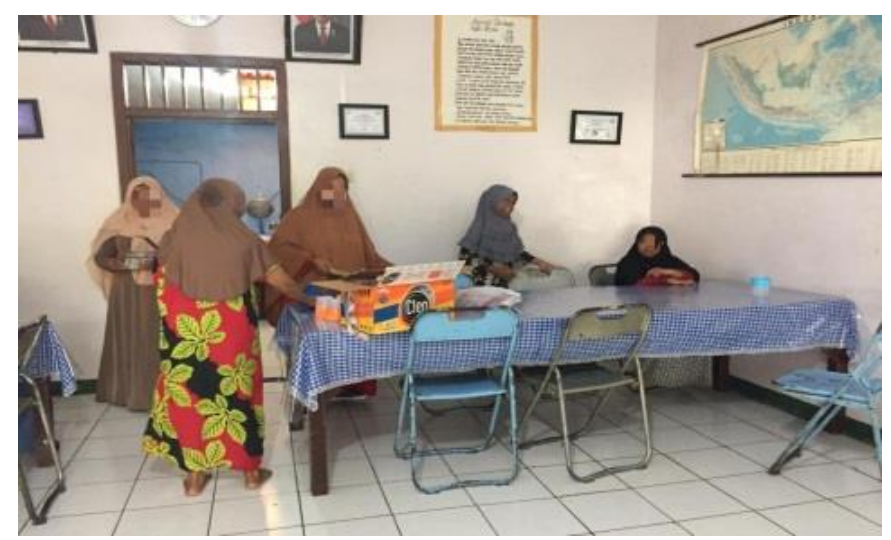

Gambar 1. Cara Pengasuh Menerapkan Sikap Empati Pada Anak Binaan

Melihat hasil dokumentasi tersebut, penulis menilai bahwa cara pengasuh menerapkan sikap empati pada anak dengan cara mengajak anak ikut membantu pengasuh mempersiapkan makan bersama, jadi dengan begitu pengasuh bisa sering berinteraksi dengan anak-anak asuh di panti asuhan, supaya anak asuh tidak merasa asing dengan pengasuh tersebut bahkan membuat adanya kedekatan dengan anak asuh.

Dari hasil data penelitian diatas dapat disimpulkan bahwa anak asuh sudah mendapatkan perhatian dari pengasuh, pengasuh selalu memperhatikan dan berinteraksi dengan anak-anak asuh di panti asuhan, seperti pengasuh selalu menjenguk kondisi anak asuh kekamar dan jika ada anak asuh yang mengalami masalah seperti sakit, ingin curhat pengasuh akan membuka diri untuk mendengarkan pesoalan anak asuh di panti asuhan.

\section{Respon anak binaan terhadap empati yang diberikan oleh pengasuh di Panti Asuhan Bumi Moro}

Berdasakan hasil wawancara dari ibu HN, pada tanggal 21 Desember 2019, ibu HN mengatakan:

"Saya sangat sensitif ketika mendengarkan anak asub ada masalah, misalnya sedih saya selalu mengbibur mereka dengan cara mengajak. duduk bersama untuk bercerita, nonton bersama supaya tidak. ada anak yang suka murung sediri, sedib dan merasa kesepian, jika ada anak asuh yang sakit saya langsung bawa ke rumah sakit atau saya beli obat saja jika tidak terlalu parah, nantik yang menjaganya ada kawan-kawan sendiri yang satu kamar. Disini juga ada anak-anak yang sedikit nakal karna mungkin masib anak-anak tetapi saya juga harus sabar dalam merawatnya walaupun itu kadang-kadang membuat kita capek dan lelah.”

Dari hasil wawancara diatas dapat disimpulkan bahwa pengasuh-pengasuh di panti asuhan sangat khawatir ketika mendengarkan keadaan-keadaan anak asuh jika tidak membaik, pengasuh selalu berinteraksi dan memperhatikan anak asuh di panti asuhan, dan selalu memberi tindakan ketika anak asuh sakit untuk membawa ke rumah sakit dan selalu menghibur ketika ada anak asuh 
sedang sedih supaya anak asuh tidak dapat merasakan kesepian di panti asuhan, karena pengasuh ikut bahagia ketika melihat anak asuhnya bahagia.

Berdasakan hasil wawancara dari anak asuh laki-laki MH, pada 23 Desember 2019, anak asuh MH mengatakan:

"Tindakan pengasuh disini baik terbadap saya kak karna kalau saya lagi sedih, suka duduk sendiri pengasub disini pasti datang pada saya menanyakan keadaan saya bagaimana, karna takut saya kenapakenapa, tetapi nantik yang mendampangi saya pas sakit atau sedib adalah kawan saya sendiri, walaupun seperti itu saya sudah merasakan ada kepedulian dari pengasub di panti asuban babkan pengasub di sini sangat sabar dalam mengurus saya disini karna selalu mengingatkan saya ketika saya buat salah."

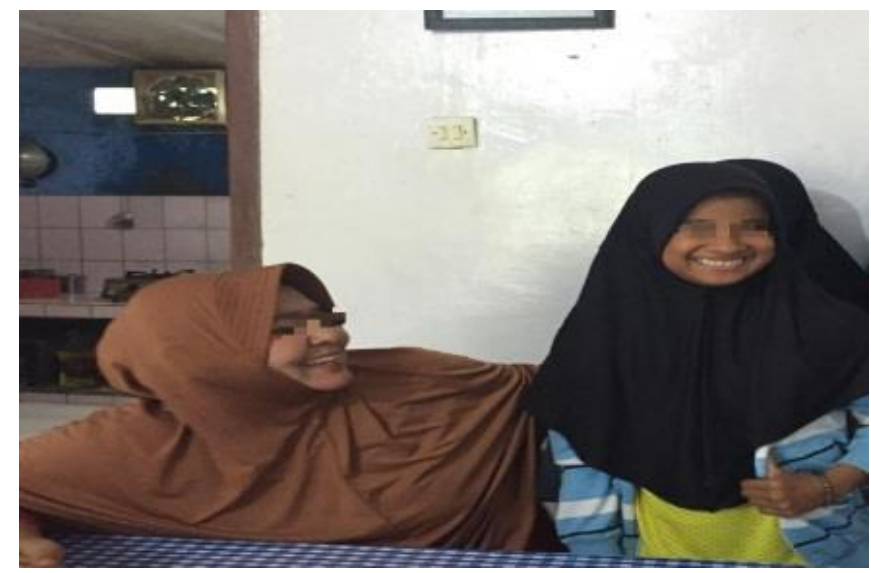

Gambar 2. Kepekaan Pengasuh Dalam Mengurus Anak Binaaan

Berdasarkan analisis gambar diatas dapat dilihat bahwa pengasuh peka dalam membuka diri untuk anak asuh di panti asuhan, dengan cara merangkul anak asuh dan memperlihatkan bahwa pengasuh sangat baik, lemah lembut dan menyayangi anak asuh.

Dari hasil data penelitian diatas dapat disimpulkan bahwa anak asuh bahagia dan nyaman tinggal di panti asuhan karena memiliki pengasuh yang baik, peka dan sabar dalam mengurus kondisi yang di alami anak asuh, memberikan tindakan ketika ada anak asuh yang sakit atau sedih, selalu menanyakan keadaannya anak asuh di panti asuhan dan selalu mengingatkan atau menegur anak asuh ketika ada yang membuat salah, maka dari itu anak asuh merasa ada yang memperhatikan dan perduli tehadap dirinya.

\section{PEMBAHASAN}

Berdasarkan deskripsi data di atas, maka pembahasan penelitian ini mencakup tiga aspek yaitu: (1) Empati pengasuh terhadapat anak binaan di Panti Asuhan Bumi Moro Kecamatan Darul Imarah Kabupaten Aceh Besar, (2) Pengasuh menerapkan sikap empati pada anak binaan di Panti Asuhan Bumo Moro Kecamatan Darul Imarah Kabupaten Aceh Besar, dan (3) 
Kepekaan pengasuh dalam mengurus anak binaaan di Panti Asuhan Bumi Moro Kecamatan Darul Imarah Kabupaten Aceh Besar.

\section{Bentuk-bentuk empati pengasuh dalam pengasuhan anak binaan di Panti Asuhan Bumi Moro kecamatan Darul Imarah Kabupaten Aceh besar}

Dari hasil data penelitian terkait bentuk-bentuk empati pengasuh dalam pengasuhan anak binaan di Panti Asuhan Bumi Moro Kecamatan Darul Imarah Kabupaten Aceh Besar, diketahui kemampuan pengasuh dalam berempati pada anak sudah berhasil dilakukan, karna dari aspekaspek empati sudah dimiliki dan dijalankan oleh pengasuh di panti asuhan. sehingga membuat pengasuh mengerti, merasakan, dan mengenal perasaan anak asuh yang seolah-olah terjadi pada dirinya malalui mau mendengarkan persoalan yang dialami anak asuh jika dalam masalah, dan pengasuh juga sangat khawatir tehadap kondisi anak asuh dan memberikan bentuk empati pada anak asuh seperti memeluk, merangkul, mengusap kepala anak asuh dan menengkan ketika anak asuh dalam masalah.

Menurut Goleman empati dibangun berdasarkan kesadaran diri. Semakin terbuka seseorang kepada emosi diri sendiri, semakin terampil pula dalam membacara perasaan. Empati adalah memahami hati, pikiran, dan jiwa orang lain termasuk motif, latar belakang, dan perasaan meraka. Semakin besar empati pada orang lain, semakin besar pula bisa menghargai dan menghormati mereka. Untuk dapat berempati pada orang lain, harus menderngarkan dengan mata dan hati kita, selain dengan telinga (Untari, 2014).

Berdasarkan hasil wawancara dan observasi peneliti dapat di simpulkan bahwa bentukbentuk empati pengasuh yang di perlihatkan kepada anak asuh seperti memeluk, merangkul, mengusap kepala anak asuh dan berusaha menenangkan ketika anak asuh dalam masalah. Jadi untuk memahami perasaan atau mendengarkan masalah anak asuh, pengasuh sudah melakukannya dengan baik, sehingga memberi respon yang positif ketika mendengarkan persoalan yang dialami oleh anak asuh di panti asuhan.

\section{Sikap pengasuh yang menunjukkan empati pada anak binaan dilihat dari verbal dan non verbal di Panti Asuhan Bumo Moro kecamatan Darul Imarah Kabupaten Aceh besar}

Bersadarkan hasil data penelitian dapat disimpukan bahwa sikap pengasuh yang menunjukkan empati pada anak binaan di Panti Asuhan, diketahui pengasuh sangat khawatir terhadap kondisi anak asuh sehingga pengasuh memberikan perhatikan terhadap anak asuh dengan cara seperti selalu menjenguk anak asuh ke kamar, sering duduk bersama anak asuh, ikut makan bersama dan sebagainya dengan tujuan supaya ada asuh merasa ada yang peduli terhadap dirinya. Oleh karena itu pengasuh tidak dapat mendampingi anak asuh seperti menjaganya 
langsung ketika ada anak asuh jatuh sakit atau sedih karena dengan jumlah anak asuh lebih banyak dari pengasuh, pengasuh hanya memperhatikannya malalui kelompok-kelompak yang ditetapkan.

Berdasarkan hasil wawancara dan observasi yang peneliti lakukan dapat dinyatakan bahwa pengasuh sudah memberikan dan menunjukkan sikap empati terhadap anak asuh di panti asuhan dengan cara:

a. Memperhatikan dengan cara menjenguk anak asuh ke kamar

b. Sering berkomunikasi dengan cara duduk bersama anak asuh di pondok

c. Kebersamaan dalam ikut serta makan bersama

d. Nonton bersama

Dengan tujuan pengasuh bisa memastikan keadaan anak asuh untuk menanyakan keadaannya supaya anak asuh merasa ada yang memperhatikan terhadap dirinya, bahkan pengasuh bisa memberikan kedekatan dengan anak asuh di panti asuhan melalui adanya kebersamaan dan inreraksi terhadap anak asuh.

\section{Respon anak binaan terhadap empati yang diberikan oleh pengasuh di Panti Asuhan Bumi Moro Kecamatan Darul Imarah Kabupaten Aceh Besar}

Dari hasil data penelitian dapat disimpulkan bahwa respon anak binaan terhadap empati yang diberikan oleh pengasuh di panti asuhan Bumi Moro Kecamatan Darul Imarah Kabupaten Aceh Besar, diketahui bahwa anak asuh bahagia bahkan nyaman dan betah tinggal di panti asuhan karena memiliki pengasuh yang baik, lemah lembut dan sayang terhadap anak asuh. pengasuh sangat khawatir dengan keadaan anak asuh sehingga membuat pengasuh peka dan sabar dalam mengurus kondisi yang di alami anak asuh, selalu mengingatkan atau menegur anak asuh ketika ada yang membuat salah, dan memberikan tindakan ketika anak asuh ada yang sakit atau sedih di panti asuhan.

Berbagi perasaan dengan yang lain dapat memelira membentuk hubungan-hubungan yang akrab. Banyak orang mengatakan bahwa mereka merasa lebih dekat setelah berbagi perasaan dan emosi. Berbagi meningkatkan rasa sosial di masyarakat dan mengurangi kerancuan dan perasaan terasing. Empati membantu mengurangi ketegangan dan mencegah konflik. Mengemukakan perasaan ketika berhubungan dengan orang-orang yang empatik membantu memaknai emosi, memaknai pengalaman, dan membantu mengendalikan perasaan (Howe, 2005).

Berdasarkan hasil wawancara dan observasi yang peneliti lakukan dapat dinyatakan bahwa anak asuh sangat bahagia karena memiliki kedekatan dengan pengasuh sehingga membuat anak asuh nyaman dan betah tinggal di panti asuhan karena memiliki pengasuh yang baik, lemah 
lembut dan pengasuh sangat yang sensitif ketika mendengarkan dan melihat anak asuh yang mengalami masalah terhadap kondisinya.

\section{PENUTUP}

Berdasarkan deskripsi dan pembahasan data penelitian maka dapat dinyatakan bahwa identifikasi sikap empati pengasuh pada anak binaan di Panti Asuhan Bumi Moro Kecamatan Darul Imarah Kabupaten Aceh Besar adalah bersikap positif.

1. Pengasuh sudah dapat memahami, merasakan, dan mengenal perasaan anak asuh yang seolaholah terjadi pada dirinya sehingga pengasuh memberikan perhatian positif terhadap anak asuhnya.

2. Pengasuh sangat khawatir terhadap anak asuh sehingga membuat pengasuh selalu menjenguk anak asuh ke kamar untuk memastika keadaan anak asuh dan menyapanya supaya anak asuh merasa ada yang memperhatikan terhadap dirinya, pengasuh sering duduk bersama bahkan nonton bersama dengan anak asuh dengan tujuan bahwa pengasuh bisa memberikan kedekatan dengan anak asuh di panti asuhan.

3. Anak asuh sangat senang dan betah tinggal di panti asuhan, karena mempunyai pengasuh yang baik dan lemah lembut dan sangat khawatir dengan keadaan anak asuh dan juga peka dan sabar dalam mengurus kondisi yang dialami anak asuh.

\section{REFERENSI}

Abdullah Nashih Ulwan, Pendidikan Anak dalam Islam, Jakarta: Pustaka Amani, 2007.

Ahmad Tafsir, Metodologi pengajaran Agama Islam, Bandung: PT. Remaja Rosdakarya, 2007.

Al-Iman Abu Ishak As-syatibi, Al- Muwafaqat Fi-Ushul As-Syariah, Beirut: Dar Al-Kutub AlIslamiah, 2001.

David Howe, Empati Makna dan Pentingnya. Yogyakarta: Pustaka Pelajar, 2005.

Davis, M.H. Mengukur Perbedaan Individu dalam Empati, (Jurnal Kepribadian dan Psikologi Sosial. Vol 44 No 1.

Depsos Ri, Petunjuk Teknik Pelaksanan Penyantunan dan Pengantasan Anak Terlantar Melalui Panti Asuban Anak, Jakarta:Binkesos, 2004.

Indra, S. (2016). Efektivitas Team Assisted Individualization untuk Mengurangi Prokrastinasi Akademik. Jurnal Edukasi: Jurnal Bimbingan Konseling, 1(2), 175-189

Indra, S., Rapono, M., \& Hayati, R. (2018). Efektivitas team Assisted Individualization untuk Meningkatkan Pemahaman pada Mata Kuliah Model-Model Konseling. Jurnal Penelitian Pendidikan Sosial Humaniora, 2(1), 141-146

Julia, H., Jarnawi, J., \& Indra, S. (2019). Pola Pengasuhan Pada Konteks Kematangan Emosional Ibu Single Parent. Indonesian Journal of Counseling and Development, 1(1), 31-49

Lexy J. Moleong, Metodologi Penelitian Kualitatif, Bandung: Remaja Rosdakarya, 2006. 
M. Quraish Shihab, Membumikan Al-Qu'ran, Bandung: Mizan, 1994.

Magdalena, DKK, Pola Pengasuban Anak Yatim Terlantar Dan Kurang Mampu Di Panti Asuhan Bunda Pengharapan (PABP) Di Kecamatan Sungai Raya Kabupaten Kubu Raya, Jurnal Tesis, (Program Stadi Sosiologi, Magister Ilmu Sosial Fakultas Ilmu Sosial dan Ilmu Politik, Universitas Tanjungpura Pontianak, 2016), Hlm. 3.

Miftah Thoha, Pembinaan Organisasi (Proses Diagnosa \& Intervensi), Jakarta: PT Raja Grapindo Persada, 2003.

Muhammad Nasib Ar-Rifa'i, Ringkasan Tafsir Ibnu Katsir Jilid 3, Jakarta: Geme Insani Pers, 1789.

Pohan, RA Pohan., \& Indra, S. (2020) Efektivitas Layanan Bimbingan Kelompok dalam Meningkatkan Kegiatan Merespon Pembelajaran. Islamic Counseling: Jurnal Bimbingan Konseling Islam, 4(1), 17-30

Puji Untari, Hubungan antara Empati dengan Sikap Pemaaf Pada Remaja Putri Yang Mengalami Kekerasan dalam Berpacaran, eJournal Psikologi, Vol. 2, 2014, ISBN: 279-289. Di akses Januari 2020.

Rudin pohan, motode penelitian pendidikan, Banda Aceh: Ar-Rijal Institute, 2007.

Sanapiah Faisal, Format-Format Penelitian Sosial, Dasar-dasar dan Aplikasil, Cet ke 3 Jakarta: RajaGrafindo Persada, 2010.

Sayyid Sabiq, Fiqib Sunnah, Jakarta: PT Tinta Abadi Gemilang, 2013.

Soehartono, Panti Asuban dalam Era Reformasi, Yogyakarta: Pustaka Pelajar, 2006.

Sofyan S. Willis, Konseling Individual Teori dan Praktek, Bandung: Alfabeta, 2011.

Sugiyono, Metode Penelitian Kuantitatif Kualitatif, R\&D Bandung: alfabeta, 2013.

Sujadi, E. (2015). Konseling Pancawaskita untuk Membentuk Problem Focused Coping. Jurnal Konseling Dan Pendidikan, 3(1), 14-24. https://doi.org/https://doi.org/10.29210/112100

Sujadi, E. (2018). Kode Etik Profesi Konseling Serta Permasalahan dalam Penerapannya.

Tarbawi: Jurnal Ilmu Pendidikan, 14(2), 69-77. https://doi.org/10.32939/tarbawi.v14i2.298

Sujadi, E. (2019). Penerapan Play Therapy dengan Menggunakan Permainan Tradisional untuk Meningkatkan Keterampilan Sosio Emosional. Jurnal Bimbingan Dan Konseling Terapan, 3(1), 14-24. https://doi.org/http://dx.doi.org/10.30598/jbkt.v3i1.892

Sujadi, E., Meditamar, M. O., Ahmad, B., \& Rahayu, A. (2018). Pengaruh Konsep Diri dan Locus of Control Terhadap Motivasi Berprestasi. Educational Guidance and Counseling Development Journal, 1(1), 32-51. https://doi.org/http://dx.doi.org/10.24014/egcdj.v1i1.4808 